\title{
The Synergy between City Human Resources and City Economy Development Based on the City Marketing: The Case of Chengdu
}

\author{
Bo $\mathrm{Pu}^{1}$ and Yanjun Qiu ${ }^{2}$ \\ ${ }^{1}$ School of Economics and Management, Southwest Jiaotong University, Chengdu 610031, China \\ ${ }^{2}$ Department of International Cooperation and Exchange and School of Civil Engineering, Southwest Jiaotong University, \\ Chengdu 610031, China \\ Correspondence should be addressed to Bo Pu; ppuubo@hotmail.com
}

Received 21 July 2014; Accepted 1 August 2014; Published 18 August 2014

Academic Editor: Guiwu Wei

Copyright (C) 2014 B. Pu and Y. Qiu. This is an open access article distributed under the Creative Commons Attribution License, which permits unrestricted use, distribution, and reproduction in any medium, provided the original work is properly cited.

\begin{abstract}
City human resources and the city economic development have a synergistic effect to attract high-quality talent and to encourage the sustainable development of the urban economy in the city marketing. Based on synergetics, we find out the evaluation indexes between the city human resources subsystem and urban economic development subsystem and constructed the evaluation system and model, and then used the yearbook data of Chengdu human resources and economic development from 2002 to 2012 and carried on empirical research. The results show that the level of coordinated development is weak between city human resources and city economic development at Chengdu, but it keeps rising slowly. The strong policy support shall be provided to Chengdu human resources and economic development by Chengdu government.
\end{abstract}

\section{Introduction}

The city is an important node and fulcrum of economic activities, political life, and cultural development. With the economic globalization, talents have been attracted by the city to expand its human resources and to promote the development of economy, so talent is critical to economic and social progress of the city. As a platform of the talent and economic development, the city should implement city marketing, in order to meet the demands of city human resources and economic growth. Therefore, it has a crucial practical significance for promoting the city economic growth and the city sustainability development to measure and test the synergy degree between city human resources and city economic development.

China is facing the pressure of urbanization; how to improve city branding, to attract high-quality talent, and to stimulate and promote economic sustainable development are an essential problem now. Chengdu is an important economic center in the West; the status of city human resources and economic development directly impact on urbanization level, and will affect the process of Chengdu's dream about "Construction of World Modern Garden City." Especially regarding the Wenchuan earthquake in 2008, whether it had impact on Chengdu human resources and economic development is just an interesting question. Talent, as a major competition in the world, has a huge promoting and pushing effect on the economic development. Under the background of city marketing, talent aggregation effect promotes the development of an urban economy effectively. Evaluation of city human resources and economic development has important practical significance for making talent introduction policy of the city and opening the municipal fiscal place. Accordingly, the research technique route was described about the synergy degree between city human resources and city economic development, as shown in Figure 1.

\section{Literature Review}

2.1. Synergy and Synergetics. As early as 1984, Haken had claimed that synergetics is a rather field of interdisciplinary research and can be of assistance to the management subject 


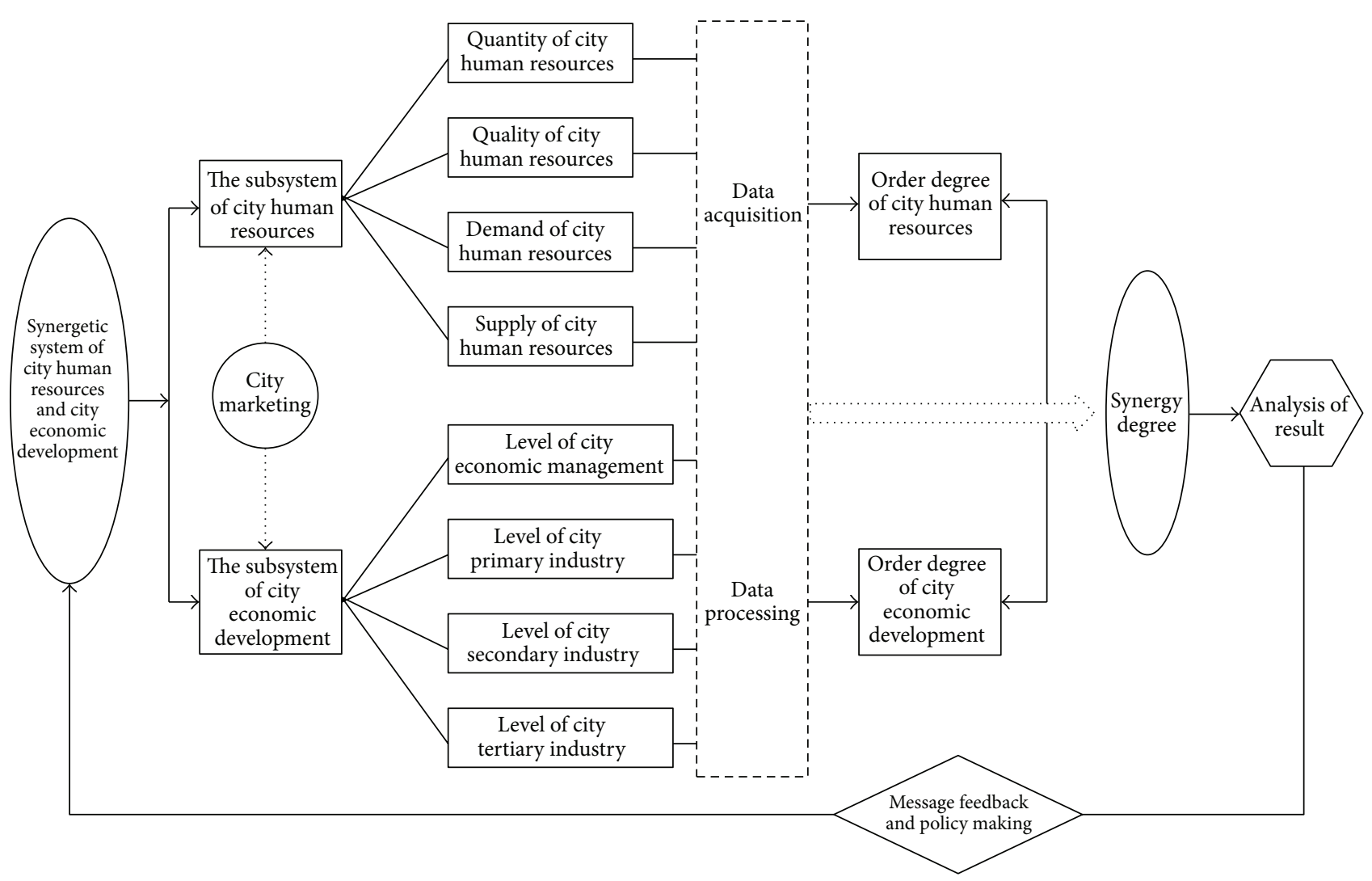

FIGURE 1: The research technique route.

[1]. Later, Knyazeva advocated that synergetics will go for a wide application field [2]. Today integration concept and synergetic theory are largely followed in modern management [3], such as a synergetic model for implementing an environmental management, occupational health, and safety management systems [4]. Some researchers paid great attention to the synergy development among the industry, scientific innovation, energy resources, and self-organization. For example, Rofiqul Islam et al., Varga, and Kuehr studied the synergy on the recovery and renewable resources $[5,6]$; di Vita and Elíasson and Turnovsky focused on the synergy development of renewable resources and the technical substitution $[7,8]$. To sum up, these studies try to use synergetics in management research but have yet to be further applied in technology and economy, business, and management studies.

2.2. City Marketing. City marketing began in the 1930s, including three stages roughly, such as "Fragmented Promotional Activities," "City Marketing Mix," and "Towards City Branding" [9-11], and several academic schools came into being on the city marketing. For instance, in the school of political orientation, Ashworth and Voogd claimed that "essentially city marketing involves the establishment of a particular relationship between producers and consumers, that is both close and permanent. This in turn necessitates the study of both the spatial and organizational structures of the city as a product as well as the characteristics, market behavior, and needs of the identified users as consumers" [12].
In the school of economics, economic development as the ultimate goal of city marketing aimed at promoting urban growth in wealth $[13,14]$. Specifically, Kotler mainly focused on two aspects between the economy (citizens, companies, and communities) and society (tourists and investors), analyzed the city marketing customers-the city human resources, such as local residents, employees, and investors. Meanwhile, Brotchie et al. scholars focused on city marketing to enhance city competitiveness and to promote the development of city economy [15]. So the city marketing is the means to achieve a city policy; city managers break through the bottleneck of urban development through the use of various marketing strategies, to enhance competitiveness [16, 17]. In addition, Kavaratzis is interested in the theory of city brand [18], Zenker et al. researched the city marketing citizen satisfaction [19], and so on. According to these studies, some subjects attract the attention of the scholars, such as the concept and scope of city marketing, the relationship between city marketing and economic development, the relationship between city marketing and human resources, city branding, and the means and motive of city marketing.

2.3. Human Resources and Economic Development. There exists a strong connection between economic growth and human development $[20,21]$. Importance of human resource development can be undeniable irrespective of developed and underdeveloped economies [22]. So the ultimate goal of economic progress is the sustainable development of human 
beings, and talent can effectively promote the development of economy. The relationship between human resource and economic development has been attracted by scholars from the perspective of macro. What is the relationship of it to the city? Manca and Fleisher et al. focus on the human capital and economic growth on region $[23,24]$. It is worth noting that Fleisher studied a related question about China and suggested that talent introduction should be undertaken for the development of social economy about the city.

From what has been reviewed above, the existing research focuses on the relationship between human resource and economic development but has not been concerned with what the coordinated development of both does. So, this study uses synergetics theory and analyses the synergy degree of city human resources and city economic development to promote the orderly development of both under the background of city marketing.

\section{Model Construction}

According to the research synergetics $[25,26]$, the model should include the changing of the associated elements between the subsystem of human resource and the subsystem of economic development, the order degree of order parameter, and the important influential factors between subsystems.

3.1. Order Parameters. Some indexes of the level of human resources development have been selected on the order parameters of the city human resources subsystem, such as quantity of city human resources, quality of city human resources, the demand of city human resources, and the supply of city human resources. Meanwhile, Some indexes of the level of city economic development have been found out about the order parameters of the city economic development subsystem, such as the management level of city economics, the level of city primary industry, the level of city secondary industry, and the level of city tertiary industry. Precise quantitative system is shown in Table 1.

3.2. Subsystem Order Degree. The composite system is an organic whole of city human resources and city economic development within the jurisdiction area of a city. In this system, the subsystem of city human resources and the subsystem of the city economy interacted with each other. Therefore, the composite system on city human resources and economic development is expressed as $s=f\left(x_{1}, x_{2}\right)$, where $x_{1}$ represents the subsystem of city human resources, $x_{2}$ is on behalf of the subsystem of city economic development, and $f$ is a composite function.

The order parameter of the subsystem of city human resources and city economic development is $x_{i j}=\left(x_{i j 1}\right.$, $\left.x_{i j 2}, \ldots, x_{i j k}\right), i \in[1, l], j \in[1, m], l \geq 1, m \geq 1$; it can describe the running state of the second subsystem $(i j)$ about city human resources and economic development, where $\alpha_{i j k}$ is upper limit and $\beta_{i j k}$ is lower limit. There are $\beta_{i j k} \leq x_{i j k} \leq \alpha_{i j k}$, $k \in[1, n]$ and $n \geq 2$.

In addition, the indicator has two kinds: one is positive index. The order degree is better when the parameter values are higher; conversely, it is the lower. The other is negative index; the order degree is better when the parameter values are lower. Order degree of order parameter $\left(x_{i j k}\right)$ can be defined

$$
Y_{i j}\left(x_{i j}\right)= \begin{cases}\frac{x_{i j k}-\beta_{i j k}}{\alpha_{i j k}-\beta_{i j k}} & (i \in[1,2], j \in[1,4], k \in[1, t]) \\ & \text { when order degree } \\ & \text { increases with } x_{i j k}, \\ \frac{\alpha_{i j k}-x_{i j k}}{\alpha_{i j k}-\beta_{i j k}} & (i \in[1,2], j \in[1,4], k \in[t+1, n]) \\ & \text { when order degree } \\ & \text { decreases with } x_{i j k},\end{cases}
$$

where $y_{i j}\left(x_{i j}\right) \in[0,1]$; its value is greater and its contribution is higher in systematic order degree.

Overall, the contribution of order parameter $\left(y_{i}\right)$ can be shown by $y_{i j}\left(x_{i j}\right)$. For using different forms of data, it is necessary to use the linear weighted sum method for data processing. The order degree model of subsystem is followed:

$$
Y_{i}\left(x_{i}\right)=\sum_{k=1}^{n} w_{k} Y_{i j}\left(x_{i j}\right), \quad w_{k} \geq 0, \sum_{k=1}^{n} w_{k}=1 \text {. }
$$

3.3. Index Weight. At present, common methods include subjective values and objective method. The former has expert scoring method and Delphi method; the later include entropy value method, the standard deviation method, and CRITIC method [27]. This study selected CRITIC method to weigh the index.

Firstly, confirming the effect of indexes

$$
C_{k}=\delta_{k} \sum_{k=1}^{n}\left(1-r_{j k}\right), \quad k=1, \ldots, n .
$$

Among them, $C_{k}$ represents the impact of the index $(k)$ on the subsystem, $\delta_{k}$ is half on the standard deviation of the index $(k)$, and $r_{j k}$ represents the correlation coefficient between the index $(j)$ and the index $(k)$. The greater the $C_{k}$ value, the more important it is to the subsystem.

Secondly, confirming the weight of index

$$
w_{k}=\frac{C_{k}}{\sum_{k=1}^{n} C_{k}}, \quad k=1, \ldots, n,
$$

where $w_{k}$ is the objective weight of the index $(k)$; then the weight coefficient was gained.

3.4. Synergy Degree Model. Synergy degree model is suitable for the quantitative description of the system development and is a function of the independent variable of the order parameter. So the function value is the system synergy degree (SD).

The subsystem order degree is $Y_{i}^{j}\left(x_{i}\right)$ when the system is at a given initial moment; after a period of time or at the next 
TABLE 1: The evaluation index of city human resources and city economic development.

\begin{tabular}{|c|c|c|c|c|}
\hline Total system & subsystem & $\begin{array}{l}\text { Order parameters of } \\
\text { the second system }\end{array}$ & $\begin{array}{l}\text { The Order parameters index of the } \\
\text { second system }\end{array}$ & units \\
\hline \multirow{22}{*}{$\begin{array}{l}\text { The system of city } \\
\text { human resource and } \\
\text { city economic } \\
\text { development } \\
\text { (s) }\end{array}$} & \multirow{12}{*}{$\begin{array}{l}\text { Subsystem of city } \\
\text { human resource } \\
\left(x_{1}\right)\end{array}$} & \multirow{3}{*}{$\begin{array}{l}\text { Quantity of human } \\
\text { resources }\left(x_{11}\right)\end{array}$} & Size of urban population $\left(x_{111}\right)$ & $\begin{array}{l}\text { Ten thousand } \\
\text { people }\end{array}$ \\
\hline & & & Size of urban labor $\left(x_{112}\right)$ & $\begin{array}{l}\text { Ten thousand } \\
\text { people }\end{array}$ \\
\hline & & & $\begin{array}{l}\text { The annual growth rate of urban } \\
\text { employment }\left(x_{113}\right)\end{array}$ & $\%$ \\
\hline & & \multirow{2}{*}{$\begin{array}{l}\text { Quality of human } \\
\text { resources }\left(x_{12}\right)\end{array}$} & $\begin{array}{l}\text { Cultural quality of human resources } \\
\left(x_{121}\right) \text { : proportion of employment got } \\
\text { Junior high school }\end{array}$ & $\%$ \\
\hline & & & $\begin{array}{l}\text { Rate of professional and technical labor } \\
\left(x_{122}\right) \text { : proportion of professional and } \\
\text { technical personnel }\end{array}$ & $\%$ \\
\hline & & \multirow{4}{*}{$\begin{array}{l}\text { Demand of human } \\
\text { resources }\left(x_{13}\right)\end{array}$} & $\begin{array}{l}\text { Rate of Innovative business labor }\left(x_{123}\right) \text { : } \\
\text { proportion of private persons }\end{array}$ & $\%$ \\
\hline & & & $\begin{array}{l}\text { Consumer demand of human resources } \\
\left(x_{131}\right) \text { : annual discretionary income per } \\
\text { capita about urban residents household }\end{array}$ & $¥$ (Yuan) \\
\hline & & & $\begin{array}{l}\text { Investment demand of human resources } \\
\left(x_{132}\right) \text { : urban residents' deposit balance }\end{array}$ & $¥$ (Billion Yuan) \\
\hline & & & $\begin{array}{l}\text { Growing demand of human resources } \\
\left(x_{133}\right) \text { : annual per capita wage }\end{array}$ & $¥$ (Yuan) \\
\hline & & \multirow{3}{*}{$\begin{array}{l}\text { Supply of human } \\
\text { resources }\left(x_{14}\right)\end{array}$} & $\begin{array}{l}\text { Education size }\left(x_{141}\right) \text { : The total number of } \\
\text { students }\end{array}$ & $\begin{array}{l}\text { Ten thousand } \\
\text { people }\end{array}$ \\
\hline & & & $\begin{array}{l}\text { Education investment }\left(x_{142}\right) \text { : education } \\
\text { from fiscal spending every year }\end{array}$ & $¥$ (Billion Yuan) \\
\hline & & & $\begin{array}{l}\text { Learning resources }\left(x_{143}\right) \text { : per capita } \\
\text { amount of books }\end{array}$ & A book \\
\hline & \multirow{10}{*}{$\begin{array}{l}\text { Subsystem of city } \\
\text { economic } \\
\text { development } \\
\left(x_{2}\right)\end{array}$} & \multirow{4}{*}{$\begin{array}{l}\text { The level of city } \\
\text { economic } \\
\text { management }\left(x_{21}\right)\end{array}$} & $\begin{array}{l}\text { Output effect per } \mathrm{km} 2\left(x_{211}\right) \text { : GDP per } \\
\text { square kilometers }\end{array}$ & $\begin{array}{l}\text { Billion Yuan } \\
\text { GDP per square } \\
\text { kilometers }\end{array}$ \\
\hline & & & $\begin{array}{l}\text { Output effect per person }\left(x_{212}\right) \text { : GDP per } \\
\text { ten thousand people }\end{array}$ & $\begin{array}{l}\text { Billion Yuan } \\
\text { GDP per ten } \\
\text { thousand people }\end{array}$ \\
\hline & & & $\begin{array}{l}\text { Water consumption of GDP }\left(x_{213}\right) \text { : water } \\
\text { consumption per ten thousand Yuan } \\
\text { GDP }\end{array}$ & $\begin{array}{l}\text { hundred million } \\
\text { tons of water per } \\
\text { ten thousand } \\
\text { Yuan of GDP }\end{array}$ \\
\hline & & & $\begin{array}{l}\text { Power consumption of GDP }\left(x_{214}\right) \text { : power } \\
\text { consumption per ten thousand Yuan } \\
\text { GDP }\end{array}$ & $\begin{array}{l}\text { hundred million } \\
\text { kwh per ten } \\
\text { thousand Yuan } \\
\text { of GDP }\end{array}$ \\
\hline & & \multirow{2}{*}{$\begin{array}{l}\text { The level of city } \\
\text { primary industry } \\
\left(x_{22}\right)\end{array}$} & $\begin{array}{l}\text { The annual growth rate of primary } \\
\text { industrial production }\left(x_{221}\right)\end{array}$ & $\%$ \\
\hline & & & $\begin{array}{l}\text { The annual growth rate of primary } \\
\text { industrial practitioners }\left(x_{222}\right)\end{array}$ & $\%$ \\
\hline & & \multirow{2}{*}{$\begin{array}{l}\text { The level of city } \\
\text { secondary industry } \\
\left(x_{23}\right)\end{array}$} & $\begin{array}{l}\text { The annual growth rate of secondary } \\
\text { industrial production }\left(x_{231}\right)\end{array}$ & $\%$ \\
\hline & & & $\begin{array}{l}\text { The annual growth rate of secondary } \\
\text { industrial practitioners }\left(x_{232}\right)\end{array}$ & $\%$ \\
\hline & & \multirow{2}{*}{$\begin{array}{l}\text { The level of city } \\
\text { tertiary } \\
\text { Industry }\left(x_{24}\right)\end{array}$} & $\begin{array}{l}\text { The annual growth rate of tertiary } \\
\text { industrial production }\left(x_{241}\right)\end{array}$ & $\%$ \\
\hline & & & $\begin{array}{l}\text { The annual growth rate of tertiary } \\
\text { industrial practitioners }\left(x_{242}\right)\end{array}$ & $\%$ \\
\hline
\end{tabular}


TABLE 2: The city marketing events of Chengdu from 2002 to 2012.

\begin{tabular}{|c|c|c|}
\hline Year & Events of city marketing & Effect \\
\hline 2002 & The Western China Investment Forum & Attracted the investment \\
\hline 2003 & $\begin{array}{l}\text { Chengdu Real Estate Industry Expo, } \\
\text { The 68th China Food and Drinks Fair }\end{array}$ & Showed habitable environment \\
\hline 2004 & $\begin{array}{l}\text { Chengdu Big Temple Fair, } \\
\text { The 70th China Food and Drinks Fair, } \\
\text { The 1st International Food and Tour Festival of China }\end{array}$ & Embodied the Chengdu culture \\
\hline 2005 & $\begin{array}{l}\text { Chengdu Image Ads "Chengdu: enjoy your life," } \\
\text { Sichuan International Friendship Cities Cooperation } \\
\text { and Development Week, } \\
\text { Chengdu Real Estate Industry Expo, } \\
\text { The 72nd China Food and Drinks Fair, } \\
\text { The 2nd International Food and Tour Festival of China }\end{array}$ & Showed the new image \\
\hline 2006 & $\begin{array}{l}\text { China First Rural Tourism Festival, } \\
\text { The 74th China Food and Drinks Fair, } \\
\text { The 3rd International Food and Tour Festival of China }\end{array}$ & $\begin{array}{l}\text { Opened the international market on } \\
\text { tourism }\end{array}$ \\
\hline 2007 & $\begin{array}{l}\text { The Reform Pilot Area of National Urban and Rural } \\
\text { Development, } \\
\text { Chengdu Gourmet Festival, } \\
\text { The Urban Forest Forum in China, } \\
\text { The 4th International Food and Tour Festival of China }\end{array}$ & $\begin{array}{l}\text { Gained the policy support, } \\
\text { won the honor "the best tourism city of } \\
\text { China" }\end{array}$ \\
\hline 2008 & $\begin{array}{l}\text { The Activity "Thanks Supports, Enjoy New Life," } \\
\text { The 78th China Food and Drinks Fair, } \\
\text { The 5th International Food and Tour Festival of China }\end{array}$ & Showed the new image of Dujiangyan \\
\hline 2009 & $\begin{array}{l}\text { The "Gold Panda Card" for Visiting } 11 \text { Chengdu } \\
\text { Attractions Freely, } \\
\text { The 80th China Food and Drinks Fair, } \\
\text { The 6th International Food and Tour Festival of China }\end{array}$ & Recalled the visitors' confidence \\
\hline 2010 & $\begin{array}{l}\text { The 82nd China Food and Drinks Fair, } \\
\text { The 7th International Food and Tour Festival of China }\end{array}$ & Gained the name "World Food City" \\
\hline 2011 & $\begin{array}{l}\text { The 84th China Food and Drinks Fair, } \\
\text { The 8th International Food and Tour Festival of China }\end{array}$ & $\begin{array}{l}\text { Won the honor "the most famous cultural } \\
\text { city in China" and "the people's livelihood } \\
\text { model city in China" }\end{array}$ \\
\hline 2012 & $\begin{array}{l}\text { The 86th China Food and Drinks Fair, } \\
\text { The 9th International Food and Tour Festival of China }\end{array}$ & $\begin{array}{l}\text { Won the honor "the best leisure city of } \\
\text { China" and "the fourth happiest cities in } \\
\text { China" }\end{array}$ \\
\hline
\end{tabular}

moment $\left(t_{j+1}\right)$, the subsystem order degree will be changed $Y_{i}^{j+1}\left(x_{i}\right)$ :

$$
\mathrm{SD}=\sqrt[n]{\left|\prod_{i=1}^{2}\left[Y_{i}^{j+1}\left(x_{i}\right)-Y_{i}^{j}\left(x_{i}\right)\right]\right|}
$$

where SD $\in[0,1]$; it embodies the synergy development between subsystems. When its value is close to 1 , the level of synergy is very good between city human resources and city economic development. When its value is close to 0 , the level is very terrible. It is noticed that the synergy degree is 0 when $Y_{i}^{j+1}\left(x_{i}\right)$ or $Y_{i}^{j}\left(x_{i}\right)$ have some questions.

\section{Empirical Study on Chengdu City}

4.1. Sampling and Data. Marketing campaigns are great weapon for city marketing, such as the cultural events [28], sports events [29], the World EXPO [30, 31], and conferences [32]. Through careful planning, these one-time and serial marketing campaigns bristle with innovative themes capable of great effect. Not only it is newsworthy, but also it is an applicable standard in the city marketing.

In this respect, Chengdu has gathered a wealth of experience in its promotion (Table 2). Many marketing campaigns have gotten the attention of tourists and investors, such as China Food and Drinks Fair every year, International Food \& Tour Festival of China every year, Fortune Global Forum in 2013, and Olympic Games in 2015. Details are shown in Table 1 .

In addition, correlated data of human resources and economic development were collected about Chengdu city. Index data came from Chengdu statistical yearbook (20022012), Sichuan statistics yearbook (2002-2012), and Chinese city statistics yearbook (2002-2012). The specific data are given in Tables 3 and 4, respectively. 
TABLE 3: Raw data of human resources subsystem of Chengdu.

\begin{tabular}{ccccccccccccc}
\hline Year & $x_{111}$ & $x_{112}$ & $x_{113}$ & $x_{121}$ & $x_{122}$ & $x_{123}$ & $x_{131}$ & $x_{132}$ & $x_{133}$ & $x_{141}$ & $x_{142}$ & $x_{143}$ \\
\hline 2002 & 1024.480 & 562.260 & 0.013 & 0.158 & 0.616 & 0.074 & 8972.000 & 6665800.000 & 12493.420 & 153.020 & 54627.000 & 0.738 \\
2003 & 1044.310 & 571.740 & 0.017 & 0.189 & 0.613 & 0.090 & 9641.000 & 9203959.000 & 13712.000 & 161.700 & 81356.000 & 0.743 \\
2004 & 1059.700 & 579.300 & 0.013 & 0.232 & 0.636 & 0.124 & 10394.000 & 14944197.000 & 15274.500 & 173.500 & 101661.000 & 0.735 \\
2005 & 1082.030 & 619.040 & 0.069 & 0.258 & 0.677 & 0.201 & 11359.000 & 17264382.000 & 17556.000 & 183.600 & 175200.000 & 0.750 \\
2006 & 1103.400 & 640.140 & 0.034 & 0.333 & 0.705 & 0.223 & 12789.000 & 20740894.000 & 19962.000 & 202.500 & 211555.000 & 0.751 \\
2007 & 1112.280 & 687.130 & 0.073 & 0.325 & 0.739 & 0.271 & 14849.000 & 24114509.000 & 22562.000 & 205.900 & 275138.000 & 0.838 \\
2008 & 1124.960 & 704.490 & 0.025 & 0.362 & 0.754 & 0.268 & 16943.000 & 24663985.000 & 26606.680 & 212.960 & 494837.000 & 0.823 \\
2009 & 1339.630 & 729.520 & 0.036 & 0.406 & 0.777 & 0.452 & 18659.000 & 32647872.000 & 27272.000 & 224.110 & 687000.000 & 1.838 \\
2010 & 1149.070 & 752.780 & 0.032 & 0.387 & 0.797 & 0.447 & 20835.000 & 42337109.000 & 30515.000 & 214.970 & 796866.000 & 1.027 \\
2011 & 1163.280 & 768.870 & 0.021 & 0.404 & 0.813 & 0.452 & 23932.000 & 51394256.000 & 34008.000 & 218.670 & 977300.000 & 1.055 \\
2012 & 1173.350 & 793.750 & 0.032 & 0.416 & 0.821 & 0.456 & 27194.000 & 59447689.000 & 38221.000 & 222.150 & 702849.000 & 1.323 \\
\hline
\end{tabular}

TABLE 4: Raw data of economic development subsystem of Chengdu.

\begin{tabular}{ccccccccccc}
\hline Year & $x_{211}$ & $x_{212}$ & $x_{213}$ & $x_{214}$ & $x_{221}$ & $x_{222}$ & $x_{231}$ & $x_{232}$ & $x_{241}$ & $x_{242}$ \\
\hline 2002 & 0.134 & 1.623 & 25.616 & 0.059 & 140.200 & 0.384 & 758.100 & 0.264 & 764.900 & 0.352 \\
2003 & 0.151 & 1.791 & 25.590 & 0.063 & 153.200 & 0.388 & 859.100 & 0.274 & 858.500 & 0.338 \\
2004 & 0.176 & 2.063 & 22.378 & 0.060 & 168.000 & 0.364 & 922.000 & 0.282 & 995.700 & 0.354 \\
2005 & 0.191 & 2.191 & 22.471 & 0.062 & 182.300 & 0.323 & 1007.700 & 0.308 & 1181.000 & 0.369 \\
2006 & 0.222 & 2.493 & 18.608 & 0.061 & 195.100 & 0.295 & 1211.600 & 0.307 & 1343.700 & 0.398 \\
2007 & 0.268 & 2.989 & 16.760 & 0.057 & 235.500 & 0.261 & 1504.000 & 0.306 & 1584.900 & 0.433 \\
2008 & 0.315 & 3.468 & 15.253 & 0.067 & 270.150 & 0.246 & 1816.660 & 0.305 & 1814.170 & 0.449 \\
2009 & 0.363 & 3.361 & 13.570 & 0.066 & 267.770 & 0.223 & 2001.800 & 0.319 & 2233.040 & 0.458 \\
2010 & 0.448 & 4.831 & 11.853 & 0.061 & 285.090 & 0.203 & 2480.900 & 0.332 & 2785.340 & 0.465 \\
2011 & 0.561 & 5.975 & 10.186 & 0.056 & 327.820 & 0.187 & 2610.800 & 0.346 & 3479.420 & 0.467 \\
2012 & 0.657 & 6.936 & 9.338 & 0.051 & 348.000 & 0.179 & 3765.620 & 0.347 & 4025.220 & 0.474 \\
\hline
\end{tabular}

4.2. Data Processing. Firstly, the original data of the index were standardized by the statistical software (SPSS21). The result was presented in Tables 5 and 6 .

Secondly, confirming the weight. According to the data from Tables 5 and 6 , the standard deviation $(\delta)$ and coefficient of correlation $(r)$ of the subsystem were found out. Then the related data were used in formula (3) and formula (4); it was not difficult to get the weight coefficient $(w)$ of the second subsystem. The weight of the second subsystem of city human resources is $w_{1}=0.099, w_{2}=0.051, w_{3}=0.269, w_{4}=0.055$, $w_{5}=0.051, w_{6}=0.049, w_{7}=0.064, w_{8}=0.069, w_{9}=$ $0.059, w_{10}=0.059, w_{11}=0.055, w_{12}=0.121$. The weight of the second subsystem of city economic development is $w_{1}=$ $0.059, w_{2}=0.063, w_{3}=0.072, w_{4}=0.349, w_{5}=0.064$, $w_{6}=0.080, w_{7}=0.067, w_{8}=0.084, w_{9}=0.060, w_{10}=0.102$.

Thirdly, confirming the synergy degree. Using the data Tables 5 and 6, the weight, and formula (2), the order parameter was drawn up. Specific data are shown in Tables 7 and 8 about an order parameter.

Finally, using the order parameter and formula (5), the synergy degree was calculated, respectively. Specific data are shown in Table 9.

4.3. Data Analysis. Order degree of Chengdu human resources subsystem presented a rising trend since 2002, but there was a sharp decline in 2006, 2008, and 2010. Figure 2

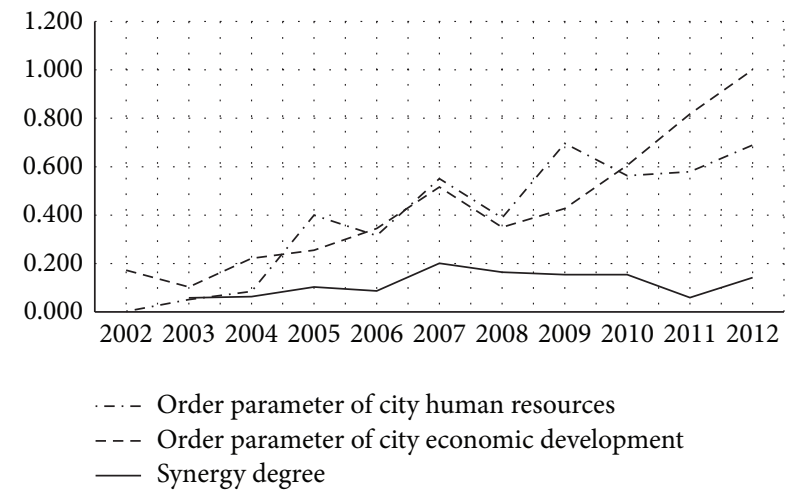

FIGURE 2: Synergy degree of human resources and economic development of Chengdu.

demonstrates that the human resources of Chengdu have been developing orderly direction. Just it was slowly and halfway down. It is notable that the order degree of subsystem was decreased in 2008; because of the earthquake, Chengdu was mistaken as "unsafe" city. With the policy support of brain gain and national disaster relief, the order degree presented a tendency of increasing in 2009.

Order degree of Chengdu economic development subsystem showed a good upward trend since 2002, but there 
TABLE 5: Standardized data of human resources subsystem of Chengdu.

\begin{tabular}{cccccccccccccc}
\hline Year & $x_{111}$ & $x_{112}$ & $x_{113}$ & $x_{121}$ & $x_{122}$ & $x_{123}$ & $x_{131}$ & $x_{132}$ & $x_{133}$ & $x_{141}$ & $x_{142}$ & $x_{143}$ \\
\hline 2002 & -1.172 & -1.332 & -0.974 & -1.707 & -1.366 & -1.343 & -1.143 & -1.221 & -1.282 & -1.756 & -1.093 & -0.662 \\
2003 & -0.941 & -1.219 & -0.807 & -1.371 & -1.404 & -1.238 & -1.033 & -1.073 & -1.139 & -1.414 & -1.012 & -0.646 \\
2004 & -0.762 & -1.128 & -0.986 & -0.911 & -1.109 & -1.014 & -0.910 & -0.738 & -0.957 & -0.948 & -0.950 & -0.669 \\
2005 & -0.502 & -0.652 & 1.737 & -0.624 & -0.584 & -0.507 & -0.752 & -0.602 & -0.691 & -0.550 & -0.727 & -0.626 \\
2006 & -0.253 & -0.400 & 0.040 & 0.187 & -0.225 & -0.362 & -0.519 & -0.399 & -0.410 & 0.195 & -0.616 & -0.624 \\
2007 & -0.150 & 0.163 & 1.973 & 0.106 & 0.211 & -0.046 & -0.182 & -0.203 & -0.106 & 0.329 & -0.423 & -0.370 \\
2008 & -0.002 & 0.370 & -0.394 & 0.508 & 0.403 & -0.066 & 0.161 & -0.170 & 0.366 & 0.607 & 0.244 & -0.415 \\
2009 & 2.497 & 0.670 & 0.111 & 0.984 & 0.698 & 1.146 & 0.441 & 0.296 & 0.444 & 1.047 & 0.828 & 2.535 \\
2010 & 0.279 & 0.948 & -0.069 & 0.776 & 0.954 & 1.113 & 0.797 & 0.861 & 0.822 & 0.687 & 1.162 & 0.178 \\
2011 & 0.444 & 1.141 & -0.585 & 0.961 & 1.159 & 1.146 & 1.304 & 1.390 & 1.230 & 0.833 & 1.710 & 0.261 \\
2012 & 0.561 & 1.439 & -0.045 & 1.090 & 1.262 & 1.172 & 1.837 & 1.860 & 1.722 & 0.970 & 0.876 & 1.039 \\
\hline
\end{tabular}

TABLE 6: Standardized data of economic development subsystem of Chengdu.

\begin{tabular}{ccccccccccc}
\hline Year & $x_{211}$ & $x_{212}$ & $x_{213}$ & $x_{214}$ & $x_{221}$ & $x_{222}$ & $x_{231}$ & $x_{232}$ & $x_{241}$ & $x_{242}$ \\
\hline 2002 & -1.051 & -1.023 & 1.377 & -0.163 & -1.316 & 1.362 & -1.029 & -1.619 & -1.049 & -1.176 \\
2003 & -0.955 & -0.928 & 1.373 & 0.632 & -1.133 & 1.413 & -0.922 & -1.253 & -0.963 & -1.441 \\
2004 & -0.809 & -0.774 & 0.833 & 0.022 & -0.926 & 1.106 & -0.854 & -0.960 & -0.838 & -1.138 \\
2005 & -0.723 & -0.701 & 0.849 & 0.345 & -0.725 & 0.582 & -0.763 & -0.007 & -0.669 & -0.855 \\
2006 & -0.547 & -0.530 & 0.200 & 0.120 & -0.545 & 0.223 & -0.545 & -0.043 & -0.521 & -0.307 \\
2007 & -0.280 & -0.249 & -0.111 & -0.787 & 0.022 & -0.212 & -0.233 & -0.080 & -0.301 & 0.354 \\
2008 & -0.013 & 0.022 & -0.364 & 1.439 & 0.509 & -0.404 & 0.101 & -0.117 & -0.092 & 0.656 \\
2009 & 0.267 & -0.039 & -0.647 & 1.190 & 0.475 & -0.698 & 0.299 & 0.397 & 0.290 & 0.826 \\
2010 & 0.753 & 0.794 & -0.936 & 0.272 & 0.718 & -0.954 & 0.811 & 0.873 & 0.794 & 0.958 \\
2011 & 1.403 & 1.442 & -1.216 & -1.008 & 1.318 & -1.158 & 0.950 & 1.386 & 1.426 & 0.996 \\
2012 & 1.955 & 1.987 & -1.358 & -2.061 & 1.602 & -1.261 & 2.184 & 1.423 & 1.924 & 1.128 \\
\hline
\end{tabular}

TABLE 7: Order parameter of human resources subsystem of Chengdu.

\begin{tabular}{cccccccccccccc}
\hline Year & $x_{111}$ & $x_{112}$ & $x_{113}$ & $x_{121}$ & $x_{122}$ & $x_{123}$ & $x_{131}$ & $x_{132}$ & $x_{133}$ & $x_{141}$ & $x_{142}$ & $x_{143}$ \\
\hline 2002 & 0.000 & 0.000 & 0.001 & 0.000 & 0.001 & 0.000 & 0.000 & 0.000 & 0.000 & 0.000 & 0.000 & 0.000 \\
2003 & 0.006 & 0.002 & 0.016 & 0.007 & 0.000 & 0.002 & 0.002 & 0.003 & 0.003 & 0.007 & 0.002 & 0.001 \\
2004 & 0.011 & 0.004 & 0.000 & 0.016 & 0.006 & 0.006 & 0.005 & 0.011 & 0.006 & 0.017 & 0.003 & 0.000 \\
2005 & 0.018 & 0.013 & 0.248 & 0.021 & 0.016 & 0.016 & 0.008 & 0.014 & 0.012 & 0.025 & 0.007 & 0.002 \\
2006 & 0.025 & 0.017 & 0.093 & 0.037 & 0.022 & 0.019 & 0.013 & 0.018 & 0.017 & 0.041 & 0.009 & 0.002 \\
2007 & 0.028 & 0.028 & 0.269 & 0.036 & 0.031 & 0.025 & 0.021 & 0.023 & 0.023 & 0.044 & 0.013 & 0.011 \\
2008 & 0.032 & 0.031 & 0.054 & 0.043 & 0.034 & 0.025 & 0.028 & 0.023 & 0.032 & 0.049 & 0.026 & 0.010 \\
2009 & 0.099 & 0.037 & 0.100 & 0.053 & 0.040 & 0.049 & 0.034 & 0.034 & 0.034 & 0.059 & 0.038 & 0.121 \\
2010 & 0.039 & 0.042 & 0.084 & 0.049 & 0.045 & 0.048 & 0.041 & 0.047 & 0.041 & 0.051 & 0.044 & 0.032 \\
2011 & 0.044 & 0.046 & 0.036 & 0.052 & 0.049 & 0.049 & 0.052 & 0.058 & 0.049 & 0.054 & 0.055 & 0.035 \\
2012 & 0.047 & 0.051 & 0.086 & 0.055 & 0.051 & 0.049 & 0.064 & 0.069 & 0.059 & 0.057 & 0.038 & 0.065 \\
\hline
\end{tabular}

was downgrading in 2003 and 2008. The order degree was affected by the SARS in 2003 and the earthquake in 2008. Some city image Ads were created under the city marketing, such as "Chengdu, enjoy your life" in 2004 and "I love my city" in 2008. The advertising video especially showed the safety of city after an earthquake and helped recovery ability of economic development. After the Wenchuan earthquake, the economic development was not only attributed to the city marketing strategy, but also attributed to the financial support of the national strategy of Chengdu. Such as the reform pilot area of national urban and rural development, the policy on the development of the western region of China, and the postdisaster rebuilding work.

Synergy degree of human resources and economic development of Chengdu is not stable, to some extent that is obviously low. The synergy degree presented a slowly rise from 2002 to 2007, but its absolute value is very slight and has great potential to increase. The synergy degree showed a gradual decline slightly from 2008 to 2011 . Here, the economic development of Chengdu was rapid; the talent also has 
TABLE 8: Order parameter of economic development subsystem of Chengdu.

\begin{tabular}{ccccccccccc}
\hline Year & $x_{211}$ & $x_{212}$ & $x_{213}$ & $x_{214}$ & $x_{221}$ & $x_{222}$ & $x_{231}$ & $x_{232}$ & $x_{241}$ & $x_{242}$ \\
\hline 2002 & 0.000 & 0.000 & 0.000 & 0.160 & 0.000 & 0.002 & 0.000 & 0.000 & 0.000 & 0.010 \\
2003 & 0.002 & 0.002 & 0.000 & 0.081 & 0.004 & 0.000 & 0.002 & 0.010 & 0.002 & 0.000 \\
2004 & 0.005 & 0.005 & 0.014 & 0.141 & 0.009 & 0.009 & 0.004 & 0.018 & 0.004 & 0.012 \\
2005 & 0.006 & 0.007 & 0.014 & 0.109 & 0.013 & 0.025 & 0.006 & 0.044 & 0.008 & 0.023 \\
2006 & 0.010 & 0.010 & 0.031 & 0.132 & 0.017 & 0.036 & 0.010 & 0.043 & 0.011 & 0.045 \\
2007 & 0.015 & 0.016 & 0.039 & 0.222 & 0.029 & 0.049 & 0.017 & 0.042 & 0.015 & 0.071 \\
2008 & 0.021 & 0.022 & 0.046 & 0.000 & 0.040 & 0.054 & 0.024 & 0.041 & 0.019 & 0.083 \\
2009 & 0.026 & 0.021 & 0.053 & 0.025 & 0.039 & 0.063 & 0.028 & 0.055 & 0.027 & 0.090 \\
2010 & 0.036 & 0.038 & 0.061 & 0.116 & 0.044 & 0.071 & 0.039 & 0.069 & 0.037 & 0.095 \\
2011 & 0.048 & 0.052 & 0.069 & 0.244 & 0.057 & 0.077 & 0.041 & 0.083 & 0.050 & 0.096 \\
2012 & 0.059 & 0.063 & 0.072 & 0.349 & 0.064 & 0.080 & 0.067 & 0.084 & 0.060 & 0.102 \\
\hline
\end{tabular}

TABle 9: Synergy degree about city human resources and city economic development.

\begin{tabular}{lccc}
\hline Year & $\begin{array}{c}\text { Order parameter of } \\
\text { human resources }\end{array}$ & $\begin{array}{c}\text { Order parameter of } \\
\text { economic } \\
\text { development }\end{array}$ & $\begin{array}{c}\text { Synergy } \\
\text { degree }\end{array}$ \\
\hline 2002 & 0.002 & 0.172 & \\
2003 & 0.051 & 0.103 & 0.058 \\
2004 & 0.084 & 0.222 & 0.063 \\
2005 & 0.399 & 0.255 & 0.103 \\
2006 & 0.315 & 0.344 & 0.087 \\
2007 & 0.550 & 0.516 & 0.201 \\
2008 & 0.388 & 0.350 & 0.164 \\
2009 & 0.696 & 0.427 & 0.154 \\
2010 & 0.562 & 0.605 & 0.154 \\
2011 & 0.579 & 0.818 & 0.059 \\
2012 & 0.689 & 1.000 & 0.142 \\
\hline
\end{tabular}

been progressing, but there were no consistent development, which is affected by the earthquake and aftershocks. In 2012, the order degree of both Chengdu human resources and Chengdu economic progress demonstrated a good upward trend. Overall, human resources and economic development of Chengdu are not completely synchronous, but it is at the low-level stage, so it is necessary to strengthen the city marketing strategy for promoting the development of the city.

\section{Conclusions and Implications}

Using the idea and method of synergetics, the model of synergy degree about city human resources and city economic development was established and the advance state of them was evaluated. These are a basement of urbanrural integration progress with the human resources policy and economic development strategy. At the same time, this study has its limitations; for example, the data are only from yearbook, the research is not covered with the social progress, and the index has yet to be further perfect.

In order to promote synergy and sustainable development of human resources and economic development of Chengdu, some work should be carried out by the government. Firstly, deepen the talent introduction policy, attract a large number of excellent talents, format talent accumulation effect, and safeguard the rights and interests of the people living standards, for promoting the sustainable development of human resources. Secondly, open the investment policy, attract the world high-tech enterprise, make the industry chain and industrial cluster, and create a sound ecological environment for investment. Finally, strengthen the synergy development of human resources and economy and promote the common development of both.

\section{Conflict of Interests}

The authors declare that there is no conflict of interests regarding the publication of this paper.

\section{Authors' Contribution}

Bo $\mathrm{Pu}$ conceived and designed the study, collected and analyzed the data, and wrote the paper. Yanjun Qiu jointly designed the study, assisted in analysis, and cowrote the paper. Bo Pu and Yanjun Qiu contributed equally to this work.

\section{Acknowledgments}

The authors thank Yude He for assistance with research methodology and Junhua Xu for English assistance. They are grateful to Southwest Jiaotong University in China, for his valuable inputs. This research was possible due to financial support from the Ministry of Education of Humanities and Social Science Project of China (no. 13YJA880058) and the National Education System Reform Pilot Project of China (no. 08-254-387).

\section{References}

[1] H. Haken, "Can synergetics be of use to management theory?" in Self-Organization and Management of Social Systems, pp. 3341, Springer, 1984.

[2] H. Knyazeva, "Synergetics and the images of future," Futures, vol. 31, no. 3-4, pp. 281-290, 1999. 
[3] M. Bobrek and M. Sokovic, "Integration concept and synergetic effect in modern management," Journal of Materials Processing Technology, vol. 175, no. 1-3, pp. 33-39, 2006.

[4] S. X. Zeng, J. J. Shi, and G. X. Lou, "A synergetic model for implementing an integrated management system: an empirical study in China," Journal of Cleaner Production, vol. 15, no. 18, pp. 1760-1767, 2007.

[5] M. Rofiqul Islam, M. Rabiul Islam, and M. Rafiqul Alam Beg, "Renewable energy resources and technologies practice in Bangladesh," Renewable and Sustainable Energy Reviews, vol. 12, no. 2, pp. 299-343, 2008.

[6] M. Varga and R. Kuehr, "Integrative approaches towards Zero Emissions regional planning: synergies of concepts," Journal of Cleaner Production, vol. 15, no. 13-14, pp. 1373-1381, 2007.

[7] G. di Vita, "Natural resources dynamics: exhaustible and renewable resources, and the rate of technical substitution," Resources Policy, vol. 31, no. 3, pp. 172-182, 2006.

[8] L. Elíasson and S. J. Turnovsky, "Renewable resources in an endogenously growing economy: balanced growth and transitional dynamics," Journal of Environmental Economics and Management, vol. 48, no. 3, pp. 1018-1049, 2004.

[9] S. Ward, Selling Places: the Marketing and Promotion of Towns and Cities 1850-2000, Routledge, 2005.

[10] A. Deffner and C. Liouris, "City marketing: a significant planning tool for urban development in a globalised economy," in Proceedings of the 45th Congress of the European Regional Science Association, pp. 486-496, Vrije Universty, Amsterdam, The Netherlands, 2005.

[11] M. Kavaratzis, "From city marketing to city branding: towards a theoretical framework for developing city brands," Place Branding, vol. 1, no. 1, pp. 58-73, 2004.

[12] G. J. Ashworth and H. Voogd, "Marketing the city: concepts, processes and Dutch applications," Town Planning Review, vol. 59, no. 1, pp. 65-79, 1988.

[13] P. Kotler, M. A. Hamlin, I. Rein, and D. H. Haider, Marketing Asian Places: Attracting Investment, Industry, and Tourism to Cities, States, and Nations, John Wiley \& Sons, New York, NY, USA, 2002.

[14] R. Paddison, "City marketing, image reconstruction and urban regeneration," Urban Studies, vol. 30, no. 2, pp. 339-350, 1993.

[15] J. Brotchie, M. Batty, E. Blakely, P. Hall, and P. Newton, Cities in Competition: Productive and Sustainable Cities for the 21st Century, Longman, Melbourne, Australia, 1995.

[16] L. D. Van Berg and E. Braun, "Urban competitiveness, marketing and the need for organising capacity," Urban Studies, vol. 36, no. 5-6, pp. 987-999, 1999.

[17] T. Metaxas, Place/City Marketing as a Tool for Local Economic Development and City's Competitiveness: A Comparative Evaluation of Place Marketing Policies in European Cities, Department of Planning and Regional development, University of Thessaly, Volos, Greece, 2002.

[18] M. Kavaratzis, "City marketing: the past, the present and some unresolved issues," Geography Compass, vol. 1, no. 3, pp. 695$712,2007$.

[19] S. Zenker, S. Petersen, and A. Aholt, "The Citizen Satisfaction Index (CSI): evidence for a four basic factor model in a German sample," Cities, vol. 31, pp. 156-164, 2013.

[20] G. Ranis, F. Stewart, and A. Ramirez, "Economic growth and human development," World Development, vol. 28, no. 2, pp. 197-219, 2000.
[21] T. Suri, M. A. Boozer, G. Ranis, and F. Stewart, "Paths to success: the relationship between human development and economic growth," World Development, vol. 39, no. 4, pp. 506-522, 2011.

[22] M. Shahbaz, N. Aamir, and S. Alam, "Is there any causality between human resource development and economic growth? A provincial case study on Pakistan," International Journal of Education Economics and Development, vol. 1, no. 2, pp. 179200, 2009.

[23] F. Manca, "Human capital composition and economic growth at the regional level," Regional Studies, vol. 46, no. 10, pp. 13671388, 2012.

[24] B. Fleisher, H. Li, and M. Q. Zhao, "Human capital, economic growth, and regional inequality in China," Journal of Development Economics, vol. 92, no. 2, pp. 215-231, 2010.

[25] Q. Yang, F. Yan, and F. Ye, "An analysis of synergy degree of primary-tertiary industry system in dujiangyan city," International Journal of Business \& Management, vol. 6, no. 8, p. 291, 2011.

[26] L. Xu and M. Cheng, "A study on Chinese regional scientific innovation efficiency with a perspective of synergy degree," Technology \& Investment, vol. 4, no. 4, 2013.

[27] S. Bhasin, R. Kamalapurkar, M. Johnson, K. G. Vamvoudakis, F. L. Lewis, and W. E. Dixon, "A novel actor-critic-identifier architecture for approximate optimal control of uncertain nonlinear systems," Automatica, vol. 49, no. 1, pp. 82-92, 2013.

[28] G. Richards and J. Wilson, "The impact of cultural events on city image: rotterdam, cultural capital of Europe 2001," Urban Studies, vol. 41, no. 10, pp. 1931-1951, 2004.

[29] A.-M. Hede, "Sports-events, tourism and destination marketing strategies: an Australian case study of Athens 2004 and its media telecast," Journal of Sport Tourism, vol. 10, no. 03, pp. 187-200, 2004.

[30] R. Lecardane and J. Zhuo, "Great event, a new strategic instrument for urban development: on the impact of world EXPO on city and society," Time + Architecture, vol. 4, 2003.

[31] L. Lamberti, G. Noci, J. Guo, and S. Zhu, "Mega-events as drivers of community participation in developing countries: the case of Shanghai World Expo," Tourism Management, vol. 32, no. 6, pp. 1474-1483, 2011.

[32] R. Davidson and T. Rogers, Marketing Destinations and Venues for Conferences, Conventions and Business Events, Routledge, New York, NY, USA, 2012. 


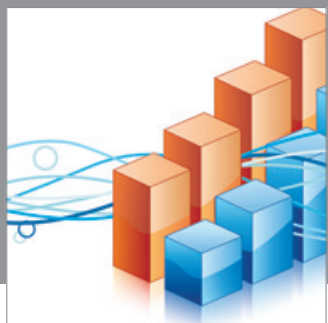

Advances in

Operations Research

mansans

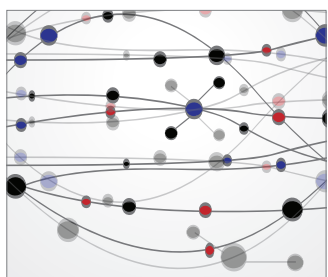

The Scientific World Journal
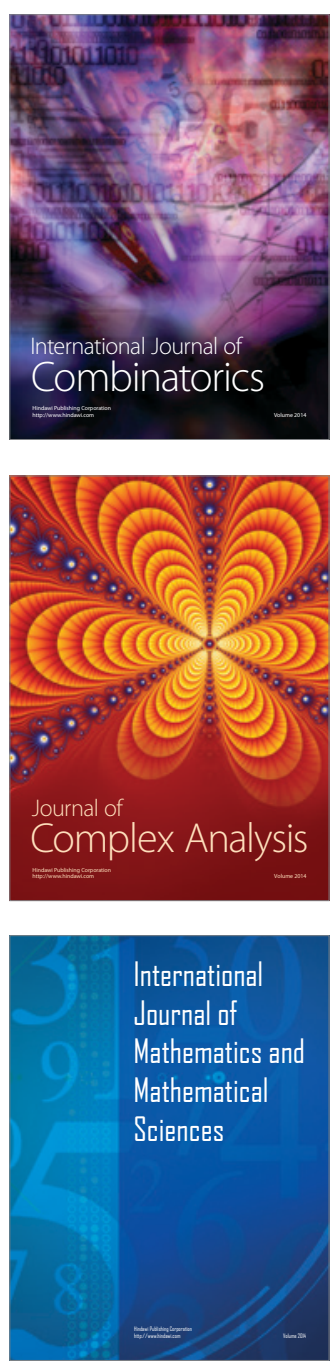
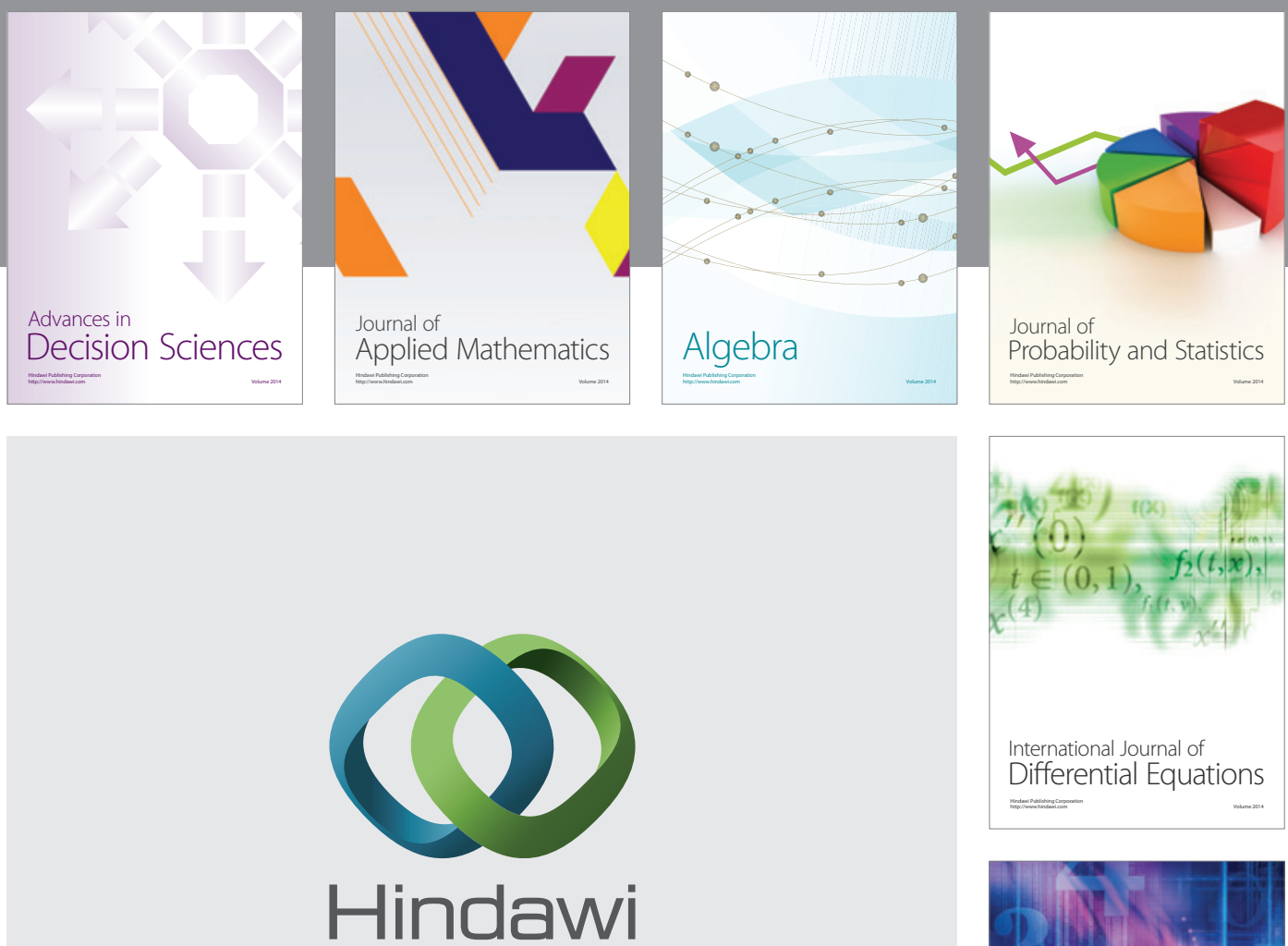

Submit your manuscripts at http://www.hindawi.com
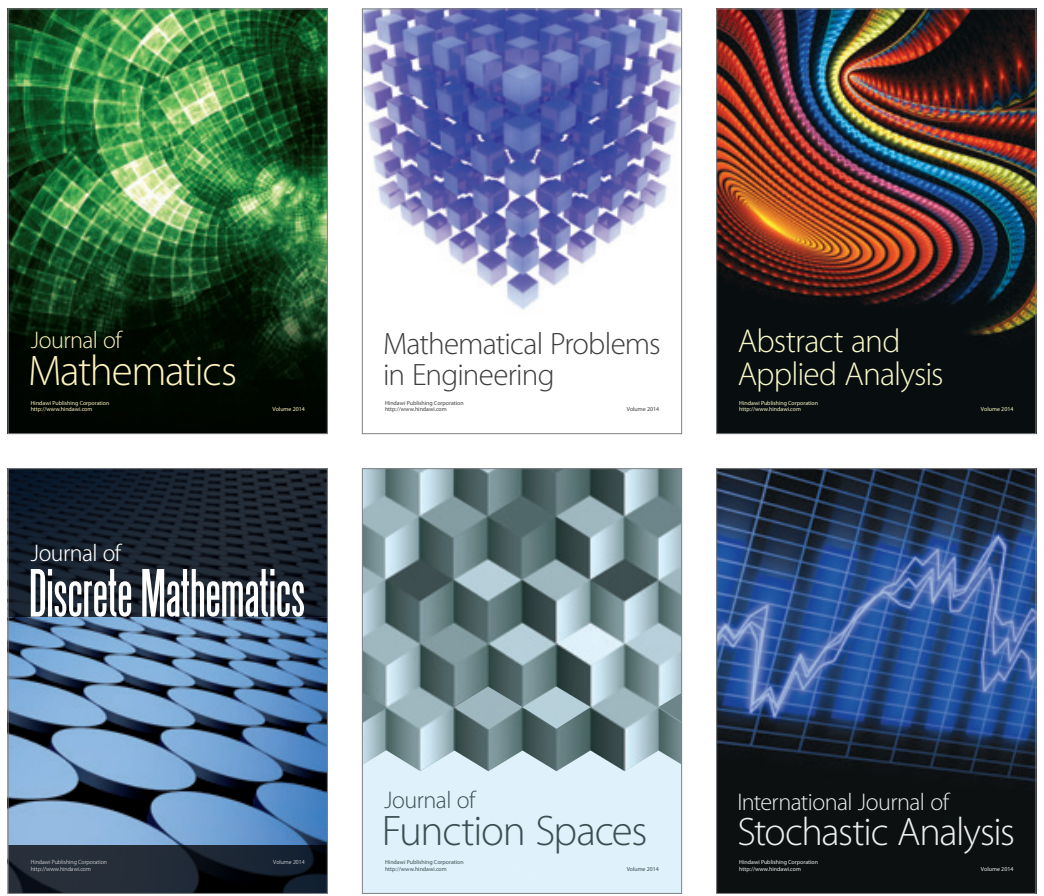

Journal of

Function Spaces

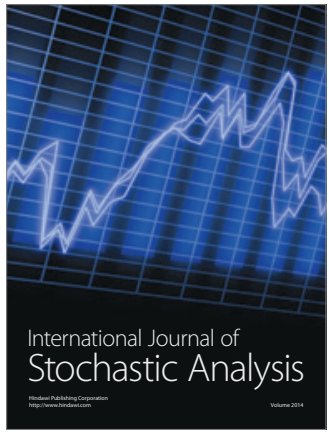

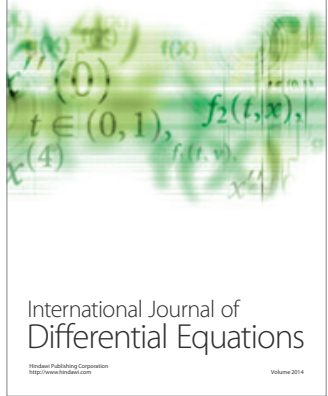
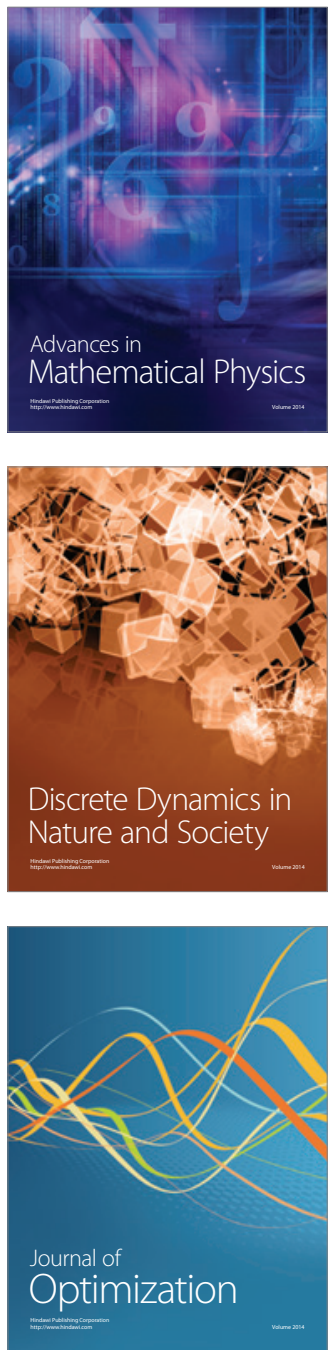